\title{
Swine Reproductive Traits under Different Housing Systems through Pre-puberty to Fifth Parity
}

\author{
Masato NAKAmURA, Yutaka Yamada \\ and Yasuhito MisAIDzU \\ National Institute of Animal Industry, Tsukuba \\ Norin Kenkyu Danchi, Ibaraki-ken 305
}

(Received October 2, 1992)

\begin{abstract}
Twelve $F_{1}$ female littermates (Landrace $\times$ Large White) were compared for reproductive performances under two different housing systems, individual stall and group pen (three/group), through pre-puberty ( $>60 \mathrm{~kg}$ in body weight) to fifth parity. They were randomly assigned to two groups across litters and fed the same feeding regime. Estrus was checked once a day with the aid of a boar and twice servicing was performed per estrus either by artificial insemination or natural service. Reproductive criteria recorded were age at first estrus, dates of first service, conception and farrowing, body weight at first estrus, at conception and at farrowing, litter size at birth and at weaning, piglet weight at birth and at weaning, percentage of weaned piglets against live born litter size, along with date of returning to estrus after first parity weaning and subsequent parities. Gilts in group pens reached puberty at an average of 24.5 days earlier than gilts in the individual stalls. Average length of the estrous cycle from the first heat to the second heat was significantly shorter $(\mathrm{P}<0.05)$ in group pen gilts than the individual stall gilts, 22.2 vs. 26.0 days. Average body weight at first service was significantly higher $(\mathrm{P}<0.05)$ in individual stall gilts than in the group pen gilts, 137.2 vs. $123.8 \mathrm{~kg}$. Litter size at birth and at weaning through all parities averaged 9.6 and 8.7 , and 11.0 and 9.4 for sows kept in the group pens and in the individual stalls, respectively. Average piglet weight at birth was significantly higher $(\mathrm{P}<0.01)$, through all parities, in group pen sows than individual stall sows, 1.55 vs. $1.32 \mathrm{~kg}$. Average piglet weight at weaning was significantly higher $(\mathrm{P}<0.01)$ in group pen sows compared to individual stall sows through all parities, 7.43 vs. $6.37 \mathrm{~kg}$. Average percentage of weaned piglets against live born litter size through all parities was significantly higher $(P<0.05)$ in group pen sows than individual stall sows, 96 vs. $88 \%$. Average interval from weaning to mating through all parities was significantly shorter $(\mathrm{P}<0.01)$ in sows kept in the group pens compared to sows in the individual stalls, 10.8 vs. 41.0 days. Individual cases of both locomotive defects and abortion were encountered in solitarily confined sows.
\end{abstract}

Anim. Sci. Technol. (Jpn.) 64 (10): 964-970, 1993

Key words : swine, reproductive performance, housing system

The confinement system used for swine breeding herds has recently been advocated as an impetus to intensify production. With most conventional systems, gilts and sows are penned either individually or in groups ${ }^{14)}$. Both of these systems have its own advantages and disadvantages. Individual housing allows discrete supervision and intensive care. It enables the animal to feed at its own pace and this further allows the ration to be regulated 
according to the animal's needs. The major drawback of this system is that it has an adverse influence on attainment of puberty as well as libido ${ }^{\left.4,9,1 n_{1} 12\right)}$. On the contrary, group confinement enhances attainment of puberty and libido ${ }^{4,9,11,12)}$. It provides more room to exercise and wider choice of 'resting place. However, the biggest disadvantage of group housing is the fighting and intimidation of weaker animals by dominant ones resulting in insufficient intake of food and rest for some. The preceding may cause some animals to abort, with remote possibility of fatalities.

Comparison of the two systems, over a shorter period, is well documented $4,5,7,9,11,22,167$, however, data on long term study is still vague. The objective of this study was to compare reproductive performances of gilts and sows kept under different housing systems through pre-puberty to reproductive ages.

\section{Materials and Methods}

Twelve $\mathrm{F}_{1}$ gilts (Landrace $\times$ Large White), six each from two different litters with an age difference of seven days, were randomly assigned before attainment of puberty (body weight $>60 \mathrm{~kg}$ ) either to be housed individually in gestation stalls or grouped in pens, three gilts per pen. Estrus was checked once a day before attainment of puberty and after weaning with the aid of a boar. Gilts were artificially inseminated using fertile Duroc boar semen twice during the second cycle. Similarly, primiparous sows were also artificially inseminated twice during the first cycle following weaning, however, multiparous sows were naturally mated twice during the first cycle following weaning. Approximately five days before expected date of farrowing, the pregnant animals were moved to farrowing stalls in a separate farrowing house. After weaning all sows were once again moved to the gestation house.

All animals were confined in the same open house during the experimental period. Indi- vidually housed animals were kept in gestation stalls $(0.7 \times 1.8 \mathrm{~m})$ separated by metallic tubes. Grouped animals were housed in two pens $(3.4 \times 4.9 \mathrm{~m})$, three animals per pen. The pens were attached to a concrete yard $(4.8 \times 4.9 \mathrm{~m})$ and a dirt lot $(5.0 \times 4.9 \mathrm{~m})$ outside. Floor of both confinement systems was made of solid concrete with the provision of sawdust bedding.

All gilts were fed individually during the growing period $(60-120 \mathrm{~kg}$ in body weight) with finishing mash (TDN $70.0 \%$, DCP 12.5\%) as recommended by Japanese Feeding Standard for Swine ${ }^{1\rangle}$. All pregnant animals received individually $2.3 \mathrm{~kg} /$ day of gestation mash (TDN 67.0\%, DCP 9.5\%) twice daily during the first and second gestational periods. This was increased to 2.5 to $3.0 \mathrm{~kg} /$ day during the later part of the gestation period, respectively. During lactating periods all sows were given $5.4 \mathrm{~kg} /$ day of finishing mash thrice daily. All piglets were fed starter mash after two weeks of age, and were weaned at four weeks of age. All sows were deprived of food for two days after weaning to suppress milk production. Each stall and pen was equipped with one watercup and water was supplied ad libitum. The experiment included up to five successive gestational and nursing periods over three years.

Reproductive criteria recorded were age at first estrus, dates of first service, conception and farrowing, body weight at first estrus, at first service, at conception and at farrowing, litter size at birth and at weaning, piglet weight at birth and at weaning, percentage of weaned piglets against live born litter size, along with date of returning to estrus after first parity weaning and subsequent parities.

Percentage data was analyzed statistically by ManN-Whitney test ${ }^{17)}$. Other data were evaluated statistically by analysis of variance for differences between treatments. 


\section{NakAmura, Yamada and Misaidzu}

\section{Results}

Comparison was made of some reproductive traits in gilts under the two different housing systems, group pen (G) and individual stall (S) (Table 1). Average age at puberty for $G$ was 24.5 days earlier than that for $S$. Average body weight at first service for $\mathrm{S}$ was significantly higher $(\mathrm{P}<0.05)$ than that for $\mathrm{G}$. Average length of the estrous cycle from the first heat to the second heat was significantly shorter $(\mathrm{P}<0.05)$ in $\mathrm{G}$ compared to $\mathrm{S}$.

Reproductive performances of the sows under the two different housing systems, $G$ and $S$, through the first to fifth parity are shown in Table 2. Average weight gain in dams during the gestation period tended to be higher in $\mathrm{G}$ compared to $S$ throughout the first to fifth parity, although the differences was not statistically significant. Delay of the average breeding age of $\mathrm{S}$ was cumulated over the three-year study. In terminal, the average breeding age of the fifth parity for $G$ was almost equivalent to the age of the fourth parity for $S$. There were no significant differences in litter sizes throughout the first to fifth parity between $G$ and $S$. The averages of birth and weaning weight for litters through all parities from $G$ were significantly higher $(P<0.01)$ than those from $S$. The average percentage of weaned piglets against the live born litter size through all parities from $G$ was

Table 2. Reproductive performances in sows under two different housing systems, group pen (G) and

\begin{tabular}{|c|c|c|c|c|}
\hline \multirow{2}{*}{ Item } & \multicolumn{2}{|c|}{ Ist parity } & \multicolumn{2}{|c|}{ 2nd parity } \\
\hline & G & S & G & $\mathrm{S}$ \\
\hline No. of sows & 6 & $5^{\mathrm{a}}$ & 6 & 5 \\
\hline Av. weight at breeding $(\mathrm{kg})^{11}$ & $\begin{array}{l}123.8^{A} \\
(11.1)\end{array}$ & $\begin{array}{l}139.4^{\mathrm{B}} \\
\left(10.0^{\circ}\right)\end{array}$ & $\begin{array}{l}154.0 \\
(3.8)\end{array}$ & $\begin{array}{l}168.8 \\
(21.4)\end{array}$ \\
\hline Av. weight gain during gestation $(\mathrm{kg})^{13}$ & $\begin{array}{c}47.2 \\
(13.4)\end{array}$ & $\left(\begin{array}{r}32.6 \\
9.1\end{array}\right)$ & $\begin{array}{c}38.2 \\
(1.9)\end{array}$ & $\begin{array}{c}33.3 \\
(16.5)\end{array}$ \\
\hline Av. breeding age (days) ${ }^{1)}$ & $\begin{array}{l}245.8 \\
(15.8)\end{array}$ & $\begin{array}{l}274.6 \\
(38.0)\end{array}$ & $\begin{array}{l}423.7 \\
(10.8)\end{array}$ & $\begin{array}{l}473.8 \\
(78.2)\end{array}$ \\
\hline Av. litter size (total born) ${ }^{11}$ & $\left(\begin{array}{l}8.0 \\
2.4\end{array}\right)$ & $\left(\begin{array}{l}8.6 \\
3.7\end{array}\right)$ & $\begin{array}{c}9.7 \\
(0.9)\end{array}$ & $\left(\begin{array}{c}12.4 \\
(1.1)\end{array}\right.$ \\
\hline Av. litter size weaned" & $\left(\begin{array}{l}7.8 \\
(2.6)\end{array}\right.$ & $\left(\begin{array}{l}7.0 \\
4.3\end{array}\right)$ & $\left(\begin{array}{l}8.7 \\
(0.0)\end{array}\right.$ & $\begin{array}{c}11.4 \\
(1.7)\end{array}$ \\
\hline Av. piglet weight at birth $\left.(\mathrm{kg})^{\mathrm{l}}\right)$ & $\begin{array}{l}1.55^{A} \\
(0.03)\end{array}$ & $\left(\begin{array}{l}1.15^{\mathrm{B}} \\
0.21)\end{array}\right.$ & $\begin{array}{l}1.63^{\mathrm{A}} \\
(0.00)\end{array}$ & $\begin{array}{l}1.35^{\mathrm{B}} \\
(0.15)\end{array}$ \\
\hline Av. piglet weight at weaning $(\mathrm{kg})^{1}$ & $\begin{array}{l}7.13 \\
1.75)\end{array}$ & $\left(\begin{array}{l}6.31 \\
1.31)\end{array}\right.$ & $\begin{array}{l}7.92^{\mathrm{A}} \\
(0.11)\end{array}$ & $\begin{array}{l}5.82^{\mathrm{B}} \\
(0.91)\end{array}$ \\
\hline Av. percentage of weaned piglets ${ }^{2)}$ & $\begin{array}{l}100.0 \\
(0.0)\end{array}$ & $\begin{array}{c}81.2 \\
(19.4)\end{array}$ & $\begin{array}{c}94.3 \\
(9.0)\end{array}$ & $\begin{array}{r}93.6 \\
(10.8)\end{array}$ \\
\hline Av. interval from weaning to mating (days) ${ }^{13}$ & $\begin{array}{r}19.5 \\
(8.2)\end{array}$ & $\begin{array}{c}35.4 \\
(28.1)\end{array}$ & $\left(\begin{array}{l}11.5 \\
(3.5)\end{array}\right.$ & $\begin{array}{c}34.0 \\
(45.3)\end{array}$ \\
\hline
\end{tabular}

( ) : Standard deviation

1): Values in $G$ through the first to fifth parity were calculated from the number of pens $(n=2)$. To-

2): Values in $G$ through the first to fifth parity were calculated from the number of sows $(n=5 \sim 6)$.

${ }^{a}$ : One gilt was excluded due to a reproductive disorder.

b: One sow was excluded due to locomotive defects.

c: One sow aborted during the fourth gestational period.

$\checkmark$ : One sow was excluded due to being a repeat breeder.

e: One sow did not return to estrus after weaning of the fourth parity.

$A, B$ : Values with different superscripts within the same row for the same parity are significantly different $C . D$ : Values with different superscripts within the same row for the same parity are significantly different 
Housing and Reproduction in Female Swine

Table 1. Comparison of reproductive traits in gilts under two different housing systems, group pen (G) and individual stall (S)

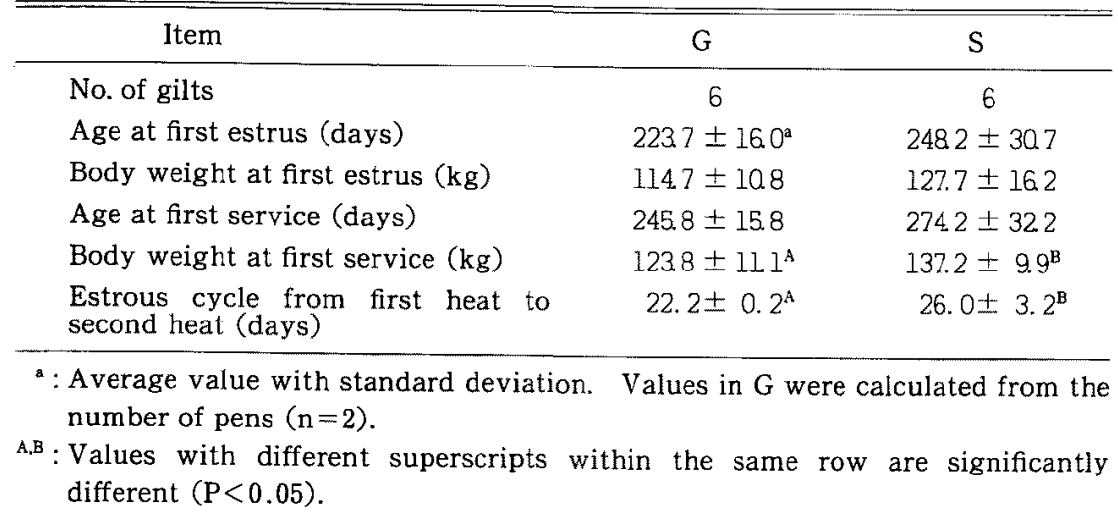

individual stall (S), through the first to fifth parity

\begin{tabular}{|c|c|c|c|c|c|c|c|}
\hline \multicolumn{2}{|c|}{ 3rd parity } & \multicolumn{2}{|c|}{ 4th parity } & \multicolumn{2}{|c|}{ 5th parity } & \multicolumn{2}{|c|}{ Total } \\
\hline G & $\mathrm{s}$ & G & $\mathrm{S}$ & G & $\mathrm{S}$ & G & $\mathrm{s}$ \\
\hline 6 & $4^{b}$ & 6 & $4^{c}$ & $5^{d}$ & $3^{e}$ & 29 & 21 \\
\hline $\begin{array}{l}168.0 \\
(1.4)\end{array}$ & $\begin{array}{l}179.6 \\
(15.7)\end{array}$ & $\begin{array}{r}177.5 \\
(8.2)\end{array}$ & $\begin{array}{l}183.5 \\
(27.2)\end{array}$ & $\begin{array}{l}191.6 \\
(15.0)\end{array}$ & $\begin{array}{l}215.3 \\
(29.8)\end{array}$ & & \\
\hline$\left(\begin{array}{l}35.0 \\
1.8\end{array}\right)$ & $\begin{array}{l}15.7 \\
(26.5)\end{array}$ & $\left(\begin{array}{c}41.0 \\
(9.0)\end{array}\right.$ & $\begin{array}{c}40.5 \\
(16.0)\end{array}$ & $\begin{array}{c}43.8 \\
(5.3)\end{array}$ & $\begin{array}{l}37.0 \\
(16.6)\end{array}$ & $\left(\begin{array}{c}41.0 \\
(7.3)\end{array}\right.$ & $\begin{array}{c}31.7 \\
(17.7)\end{array}$ \\
\hline $\begin{array}{l}578.8 \\
(15.8)\end{array}$ & $\begin{array}{l}634.5 \\
(64.7)\end{array}$ & $\begin{array}{l}732.3^{\mathrm{c}} \\
(15.6)\end{array}$ & $\begin{array}{l}885.0^{D} \\
\left(85.3^{3}\right)\end{array}$ & $\begin{array}{l}890.6^{c} \\
(4.4)\end{array}$ & $\begin{array}{c}1053.7^{\mathrm{D}} \\
\left(32.5^{2}\right)\end{array}$ & & \\
\hline$\left(\begin{array}{l}8.3 \\
2.8\end{array}\right)$ & $\begin{array}{c}11.5 \\
(3.1)\end{array}$ & $\left(\begin{array}{l}9.7 \\
(2.4\end{array}\right)$ & $\left(\begin{array}{r}12.8 \\
(5.7)\end{array}\right.$ & $\begin{array}{c}12.3 \\
(2.4)\end{array}$ & $\begin{array}{l}10.0 \\
(6.2)\end{array}$ & $\left(\begin{array}{l}9.6 \\
2.3\end{array}\right)$ & $\begin{array}{c}11.0 \\
(4.1)\end{array}$ \\
\hline$\left(\begin{array}{l}7.2 \\
3.1\end{array}\right)$ & $\left(\begin{array}{l}10.3 \\
(3.3)\end{array}\right.$ & $\left(\begin{array}{l}8.3 \\
(1.4)\end{array}\right.$ & $\left(\begin{array}{l}9.5 \\
3.1\end{array}\right)$ & $\left(\begin{array}{ll}11.5 \\
(2.1)\end{array}\right.$ & $\begin{array}{l}8.7 \\
(5.5)\end{array}$ & $\left(\begin{array}{l}8.7 \\
2.2\end{array}\right)$ & $\left(\begin{array}{l}9.4 \\
(3.6)\end{array}\right.$ \\
\hline $\begin{array}{l}1.55 \\
(0.01)\end{array}$ & $\begin{array}{l}1.34 \\
(0.17)\end{array}$ & $\begin{array}{l}1.55^{\mathrm{A}} \\
(0.09)\end{array}$ & $\begin{array}{l}1.17^{\mathrm{B}} \\
(0.28)\end{array}$ & $\begin{array}{l}1.47 \\
(0.05)\end{array}$ & $\begin{array}{l}1.75 \\
(0.51)\end{array}$ & $\begin{array}{l}1.55^{\mathrm{c}} \\
(0.06)\end{array}$ & $\begin{array}{l}1.32^{\mathrm{D}} \\
(0.31)\end{array}$ \\
\hline $\begin{array}{l}8.04 \\
(0.29)\end{array}$ & $\begin{array}{l}6.13 \\
(0.93)\end{array}$ & $\begin{array}{l}7.58 \\
\text { ( } 1.33)\end{array}$ & $\left(\begin{array}{l}6.09 \\
(0.45)\end{array}\right.$ & $\begin{array}{l}6.50 \\
(0.70)\end{array}$ & $\begin{array}{l}8.06 \\
(2.47)\end{array}$ & $\begin{array}{l}7.43^{\mathrm{c}} \\
(0.97)\end{array}$ & $\begin{array}{l}6.37^{\mathrm{D}} \\
(1.34)\end{array}$ \\
\hline $\begin{array}{l}93.5 \\
(10.2)\end{array}$ & $\left(\begin{array}{c}88.4 \\
(7.8)\end{array}\right.$ & $\begin{array}{c}92.7 \\
(9.0)\end{array}$ & $\begin{array}{c}83.9 \\
(12.8)\end{array}$ & $\begin{array}{c}97.6 \\
(5.3)\end{array}$ & $\left(\begin{array}{c}96.7 \\
(5.8)\end{array}\right.$ & $\begin{array}{c}95.6^{\mathrm{A}} \\
\left(7.7^{2}\right)\end{array}$ & $\begin{array}{l}88.2^{\mathbf{B}} \\
\left(13.0^{\circ}\right)\end{array}$ \\
\hline $\begin{array}{l}9.7^{\mathrm{A}} \\
\left(0.5^{2}\right)\end{array}$ & $\begin{array}{c}95.0^{\mathrm{E}} \\
(88.9)\end{array}$ & $\left(\begin{array}{l}6.3 \\
(0.5)\end{array}\right)$ & $\begin{array}{l}9.0 \\
(5.3)\end{array}$ & $\begin{array}{l}6.8 \\
(1.8)\end{array}$ & $\begin{array}{l}19.7 \\
(14.2)\end{array}$ & $\left.\begin{array}{c}10.8^{\circ} \\
(5.9\end{array}\right)$ & $\begin{array}{l}41,0^{\mathrm{D}} \\
(52,7)\end{array}$ \\
\hline
\end{tabular}

tal values in $G$ were calculated from the total number of pens $(n=10)$.

Total value in $G$ was calculated from the total number of sows $(n=29)$.

$(P<0.05)$.

$(P<0.01)$. 
significantly higher $(\mathrm{P}<0.05)$ compared to $\mathrm{S}$. The average interval from weaning to mating through all parities was significantly shorter $(\mathrm{P}<0.01)$ in $\mathrm{G}$ compared to $\mathrm{S}$.

\section{Discussion}

In this study, onset of puberty was delayed in gilts housed in individual stalls compared to those in group pens. This finding accords with some earlier reports $s^{9,11,12)}$. The first estrous cycle of gilts in individual stalls was also longer than that of gilts in group pens. ENGLAND and SPURR ${ }^{4}$ reported that coupling was frequently difficult in individually housed gilts either due to a complete absence or irregular expression of overt estrous signs or an unwillingness to mate. Further, it has been suggested that stress interferes with the normal sexual development and onset of estrus $^{9 \prime}$. In this study, delayed puberty in individually stalled gilts was presumably caused by limited exercise in the small stalls, plus added effect of psychological stress arising from individual confinement. In contrast, RAMPACEK et al. ${ }^{15)}$ was of the opinion that confined-induced delayed puberty in gilts was not primarily caused by stress.

In the present study, the average interval from weaning to mating tended to be shorter in sows housed in group pens compared to sows in individual stalls throughout first to fifth parity. Previous studies also reported a similar trend of reduced weaning-to-mating interval in group-housed as opposed to individually-housed sows ${ }^{7,16)}$, although their data was not clear-cut. On the contrary, FAHMY and Dufour ${ }^{5)}$ noted that the weaningestrus interval was shorter for sows housed individually than those housed in groups.

BARNETT et al. ${ }^{2)}$ found that individually housed gilts, compared to grouped gilts, tended to suffer from chronic stress. Furthermore, chronic stress has also been found to affect the pituitary-ovarian axis in the gilt ${ }^{8)}$ and the sow ${ }^{10)}$. In the present study, grouped sows could freely select a comfortable place to rest within the pen, whereas, sows housed in individual stalls were often forced to lie on their own feces and urine even under extreme weather conditions. Moreover, there was no opportunity for individual sows in stalls to huddle, in contrast to grouped sows. Considering these factors, chronic stress in individually stalled sows seems to contribute to the longer period to return to estrus after weaning.

Average piglet weight at birth and at weaning in grouped sows was higher than in individually housed sows through first to fourth parity in this study. ENGLAND and SPURR ${ }^{4)}$ reported that the average birth weight per pig was significantly higher in group-housed sows than in individually confined sows, but in their study no significant difference was observed in litters from gilts housed under the two confinement systems. MEACHAM and MAsINCUPP ${ }^{12)}$ found a beneficial effect on birth and weaning weight of piglets when the sow or gilt was kept outside during gestation. In the present study, the average weight gain in dams during gestation periods tended to be higher in grouped sows than in individually housed sows throughout first to fif th parity. Thus, improved body weight of piglets in this study could be attributable to superior body conditions of the dams during gestation and also to better milk production in grouped sows.

Average percentage of weaned piglets against live born litter size in this study was higher in grouped sows than in individually housed sows throughout first to fifth parity. Bille et al. ${ }^{3)}$ reported that asphyxia during parturition may influence the viability of live-born piglets and that perinatal losses in litters from sows tied up or kept in small boxes was significantly higher than in litters from sows housed in pens during pregnancy. The higher percentage of weaned piglets from grouped sows than individually stalled sows in this study could be attributable to heavier birth weights.

In the present study, individual cases of both 


\section{Housing and Reproduction in Female Swine}

locomotive defects and abortion were encountered in solitarily confined sows. HaLE et al. ${ }^{6)}$ found a higher percentage of locomotive defects in gilts confined to a restricted area with minimum room for exercise. Locomotive defects in this study could be attributable to uncomfortable residence in individual stalls, resulting in leg weakness during the growingfinishing period. The cause of abortion in this study was not determined. However, MUIRHEAD ${ }^{(3)}$ had earlier reported that confined sows are dirtier than loose sows and are often forced to lie on their own feces and urine, which can lead to urogenital tract infections and serious losses in reproductive performances.

In summary, the reproductive performances of grouped sows was superior than that of individually stalled sows over the three-year duration of this study. Therefore, stall housing can not be eliminated as a possible deterrent to swine productivity through pre-puberty to reproductive ages. However, our study did not clearly define the psychological effects of individual confinement along with physical distress due to space restriction and their consequence on swine productivity. Further carefully controlled comparative experiments are needed before definite conclusions can be drawn on the best housing system for optimum productivity.

\section{References}

1) Agriculture, Forestry and Fisheries Research Council Secretariat, Ministry of Agriculture, Forestry and Fisheries, Japanese Feeding Standard for Swine (1975). 6th ed. 10-11. Chuochikusankai. Tokyo. 1982. (in Japanese).

2) Barnetr, J.L., G.M. Cronin and C.G. WINFIELD, The effects of individual and group penning of pigs on total and free plasma corticosteroids and the maximum corticosteroid binding capacity. Gen. Comp. Endocr., 44: 219-225. 1981.

3) Bille, N., N.C. Nielsen, J.L. Larsen and J. SVENDSEN, Preweaning mortality in pigs. 2. The perinatal period. Nord. Vet. Med., 26 : 294-313. 1974.

4) England, D.C. and D.T. Spurr, Litter size of swine confined during gestation. J. Anim. Sci., 28: 220-223. 1969.

5) FAHMY, M.H. and J.J. Dufour, Effects of post-weaning stress and feeding management on return to oestrus and reproductive traits during early pregnancy in swine. Anim. Prod., 23 : 103-110. 1976.

6) Hale, O.M., G.L. Newton and E.R. Cleveland, Effects of exercise during the growing-finishing period on performance, age at puberty and conception rate of gilts. J. Anim. Sci., 58: 541-544. 1984.

7) Hemsworth, P.H., N.T.C.J. SAlden and A. HoogerbrugGe, The influence of the postweaning social environment on the weaning to mating interval of the sow. Anim. Prod., 35 : 41-48. 1982.

8) Hennessy, D.P. and P. Williamson, The effects of stress and of ACTH administration in hormone profiles, oestrus and ovulation in pigs. Theriogenology, $20: 13^{-}$ 26. 1983.

9) Jensen, A.H., J.T. Yen, M.M. Gehring, D.H. BAKER, D.E. BECKER and B.G. HARMON, Effects of space restriction and management on pre- and post-puberal response of female swine. J. Anim. Sci., $31: 745-750.1970$.

10) Liptrap. R.M., Effect of corticotrophin and corticosteroids on oestrus, ovulation and oestrogen excretion in the sow. J. Endocr., 47: 197-205. 1970.

11) Mavrogenis, A.P. and O.W. Robison, Factors affecting puberty in swine. $J$. Anim. Sci., 42 : 1251-1255. 1976.

12) Meacham, T.N. and F.B. Masincupp, Effect of confinement on reproduction and several blood components in gilts (Abstact). J. Anim. Sci., $31: 226.1970$.

13) MurrheAd, M.R., Pig housing and environment. Vet. Rec, $113:$ 587-593. 1983.

14) Petherick, J.C. and J.K. Blackshaw, A review of housing systems for non-lactating sows. Pig News and Information, 7 ; 33-38. 1986.

15) Rampacek, G.B., R.R. Kraei.jng, E.S. FONDA and C.R. BARB, Comparison of physiological indicators of chronic stress in confined and nonconfined gilts. J. Anim. Sci., 58 : 401-408. 1984. 
16) Schmidt, W.E., J.S. Stevenson and D.L. DAvis, Reproductive traits of sows penned individually or in groups until 35 days after breeding. J. Anim. Sci., 60 : 755-759.
1985.

17) Snedecor, G.W. and W.G. Cochran, Statistical Methods. 6th ed. 125-126. Iwanami Press. Tokyo. 1972. (in Japanese).

\title{
性成熟前から 5 産次まで異なる飼養方式を 継続した雌豚の繁殖成績
}

\author{
中村正斗・山田 豊・美齊津康民
}

農林水産省畜産試験場, 茨城県筑波農林研究団地 305

\begin{abstract}
同腹の繁殖雌豚を 2 種の飼養力式で 3 年間飼育し, 発情と産子成績を比較した. 12 頭のランドレー

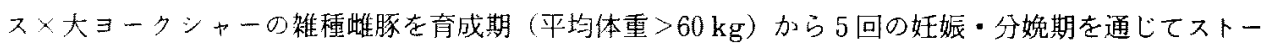
ルで単飼または豚房内で 3 頭ずつ群飼した，各区に同腹豚を無作為に配置し，育成期加ら発情を每日調 べ，性成熟捘 2 回目の発情㧍よひ離乳後の初回発情に人工授精または自然交配を行なった，供試豚はす べて,同一の慗殖ステージには同一の飼料を個別給与した。初回発情時の日龄势よび体重，受胎時の日

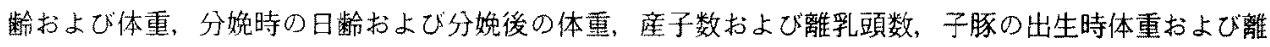
乳時体重，離乳時の子豚の育成率および離乳後の発情再帰日数について初産から 5 産まで調べた。平均 初回発情日齢は，群飼豚がストール飼育豚上りも24.5日早かった，初回発情から 2 回目の発情までの 平均発情周期は, 群飼豚（22.2日）がストール飼育豚（26.0日）上り西有意に短功た（ $\mathrm{P}<0.05 ）$. 初回交配時の平均体重は，ストール飼育豚 $(137.2 \mathrm{~kg})$ 加群飼豚 $(123.8 \mathrm{~kg})$ よりも有意に重かった $(\mathrm{P}<0.05)$. 平均産子数之離乳頭数は, 群飼豚でそれぞれ 9.6 頭术よび 8.7 頭, ストール飼育豚でそれ ぞれ 11.0 頭および 9.4 頭であった。群飼豚の子豚の出生時の平均体重 $(1.55 \mathrm{~kg})$ はスト一ル飼育豚の それ（1.32 kg）よりも有意に重かった（P<0.01）。群飼豚の子豚の離乳時の平均体重 $(7.43 \mathrm{~kg})$ は スト一ル飼育豚のそれ $(6.37 \mathrm{~kg})$ 上りも有意に重かった $(\mathrm{P}<0.01)$. 群飼豚の子豚の離乳時の平均育

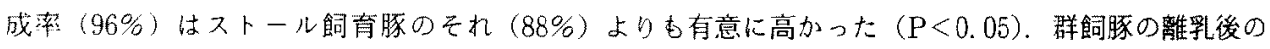
平均発情雨㷌日数（10.8日）はストール飼育豚のそれ（41.0日）より有意に短加った（P<0.01）. ストール飼育豚では運動器障害と流産の発生が浔められた。
\end{abstract}

日畜会報, $64(10) ： 964-970,1993$ 